\title{
Implementasi Sistem Informasi untuk Pemantauan dan Evaluasi Efektivitas E-Learning
}

\author{
Farida Nurlaila ${ }^{1}$, Joko Riyanto ${ }^{2}$, dan Fajar Agung Nugroho ${ }^{3}$ \\ 1,2,3 Teknik Informatika, Universitas Pamulang, Jl. Surya Kencana No. 1 Pamulang, Tangerang \\ Selatan, 15417 \\ e-mail: 1dosen00676@unpam.ac.id, 2jokoriyanto@unpam.ac.id, ${ }^{3}$ fajaragungnugroho@unpam.ac.id
}

Submitted Date: August $05^{\text {th }}, 2020$

Revised Date: October 02 $2^{\text {nd }}, 2020$

\author{
Reviewed Date: September $22^{\text {nd }}, 2020$ \\ Accepted Date: January $04^{\text {th }}, 2021$
}

\begin{abstract}
This study discusses the monitoring and evaluation of e-learning activities through the LMS (Learning Management System) application of Pamulang University. In the previous process, the system used could only display activities carried out by lecturers that were recorded in the e-learning log. The logs that are displayed only create, update, delete activity, and cannot provide information about the effectiveness of online learning. Other parameters are needed to measure the effectiveness of online learning. One of them is the number of activities lecturers have to do for each subject within a certain period. In each course, the lecturer activity frequency is called create. Create is intended to open discussion topics by providing questions and responses to students' answers. From the results of monitoring, the achievement of creation is not sufficient to determine the success of implementing e-learning at Pamulang University. So that several other restrictions are needed such as participation, intensity, and content suitability. However, problems that occur in other parameters cannot be monitored just by looking at the data from the e-learning log. From these problems, a visual presentation of the activities of lecturers and students is needed which allows Study Programs with low percentages to be identified as quickly as possible, and decision making can be determined. The results showed that the four parameters can be implemented in the system. The average value of student participation in discussion forums is $74.99 \%$, the ratio of the intensity of the activeness of lecturers and students every day of the week during the implementation period is $49.40 \%$. Then the content suitability obtained an average of $0.04 \%$ and an average value of $65.90 \%$ lecturer activity. The generating facility automatically shows the four parameters in cooperation with the final result considered to assess the effectiveness of e-learning.
\end{abstract}

Keywords: controlling; evaluating; effectiveness; e-learning; Pamulang University

\section{Abstrak}

Penelitian ini membahas aktifitas pemantauan dan evaluasi kegiatan e-learning melalui aplikasi LMS (Learning Management System) Universitas Pamulang . Pada proses sebelumnya, sistem yang digunakan hanya dapat menampilkan aktifitas yang dilakukan oleh dosen yang tercatat di log e-learning. Log yang tercatat hanya menampilkan aktifitas create, update, delete dan tidak dapat memberikan informasi terkait efektivitas pada pembelajaran online. Dibutuhkan parameter lain untuk mengukur efektivitas pembelajaran online. Salah satunya adalah jumlah aktifitas yang harus dilakukan dosen untuk setiap course dalam periode tertentu. Dalam setiap course, frekuensi kegiatan dosen dinamakan create. Create yang dimaksud adalah membuka topik diskusi dengan memberikan pertanyaan dan tanggapan terhadap jawaban mahasiswa. Dari hasil pemantauan yang dilakukan, pencapaian create tidak cukup untuk menentukan keberhasilan implementasi e-learning di Universitas Pamulang. Maka, dibutuhkan beberapa batasan lain seperti partisipasi, intensitas, dan kesesuaian konten. Namun, masalah yang terjadi pada parameter lainnya tidak dapat dipantau dengan hanya melihat data yang berasal dari log e-learning. Dari masalah tersebut, dibutuhkan penyajian visual tentang kegiatan dosen dan mahasiswa yang memungkinkan Program Studi dengan persentase rendah diidentifikasi sesegera mungkin dan pengambilan keputusan dapat ditentukan. Hasil penelitian menunjukkan bahwa keempat parameter dapat diimplementasikan dalam sistem. Nilai 
partisipasi mahasiswa yang aktif dalam forum diskusi rata-rata $74,99 \%$, perbandingan intensitas keaktifan dosen dan mahasiswa setiap hari dalam seminggu selama periode pelaksanaan sebesar 49,40\%. Kemudian, kesesuaian konten didapatkan rata-rata $0,04 \%$ dan untuk nilai rata-rata aktifitas dosen sebesar $65,90 \%$. Fasilitas generate secara otomatis menunjukkan empat parameter dalam bekerja bersama dengan mempertimbangkan hasil terakhir untuk menilai keefektifan e-learning.

Kata kunci: mengontrol; mengevaluasi; efektivitas; e-learning; Universitas Pamulang

\section{Pendahuluan}

Internet telah menjadi salah satu cara vital untuk memfasilitasi komunikasi saat ini. Dari data yang dilansir dari laporan survei APJII (Asosiasi Penyelenggara Jasa Internet Indonesia) tahun 2018, jumlah pengguna internet di Indonesia tercatat dengan total pengakses sebesar 171,17 juta orang dengan peningkatan sebesar 27,91 juta orang dari tahun sebelumnya.

Bukan tidak mungkin membuat sumber daya yang tersedia untuk penelitian dan pembelajaran bagi guru dan siswa untuk berbagi dan memperoleh informasi. Hal ini erat kaitannya dengan model pembelajaran e-learning yang diartikan sebagai bentuk pembelajaran konvensional yang disajikan dalam format digital dengan dukungan teknologi internet. Tidak hanya untuk pembelajaran konvensional saja, sistem ini juga dapat digunakan dalam pendidikan jarak jauh. Oleh sebab itu, pengembangan model pembelajaran ini tidak sekedar menyajikan materi pelajaran melalui media internet tetapi perlu pertimbangan secara logis dan memegang prinsip pembelajaran (Silahuddin, 2015). Pembelajaran online membutuhkan sumber daya yang baik dalam menangani dan perencanaan yang cermat. Dalam hal ini, guru bertindak tidak hanya memberikan konten pengetahuan tetapi sebagai fasilitator dan TIK dianggap sebagai sumber daya yang meningkatkan pengalaman belajar siswa. Dengan belajar melalui e-learning, telah mengembalikan semangat peserta didik dalam belajar melalui pengiriman konten yang inovatif dan interaktif dan telah terbukti lebih menarik bagi siswa (Dhull \& Sakshi, 2017). Untuk melihat keberhasilan penyelenggaraan e-learning maka perlu dilakukan evaluasi untuk mengukur keberhasilan pembelajaran maupun penyelenggaraan e-learning. Sebuah penelitian menyatakan bahwa faktor-faktor dasar yang mempengaruhi keberhasilan implementasi elearning adalah teknologi, karakteristik pengajar, karakteristik siswa. Namun, pada negara berkembang ada beberapa karakteristik lain agar elearning berjalan secara maksimal yaitu lingkungan e-learning, kualitas institusi dan layanan, infrastuktur dan kualitas sistem, kualitas kursus dan informasi serta motivasi (Pangondian, Santosa, \& Nugroho, 2019).

Penelitian ini mengambil lokasi di Universitas Pamulang, di mana pengambilan sample dilakukan pada 8 Program Studi menggunakan e-learning sebagai penunjang dalam proses pembelajaran. Hal yang akan dibahas dalam penelitian ini adalah proses evaluasi e-learning. Pada dasarnya setiap aktifitas yang dilakukan oleh dosen tercatat di log e-learning. Namun, dari log tersebut tidak dapat memberikan informasi terkait efektivitas pada pembelajaran online. Log yang tercatat hanya menampilkan aktifitas create, update dan delete yang dilakukan oleh dosen pada forum diskusi, kegiatan yang dimaksud adalah membuka topik diskusi dengan memberikan pertanyaan dan tanggapan terhadap jawaban mahasiswa. Dari hasil pemantauan terhadap aktivitas tersebut, tidak cukup menjadi tolak ukur keberhasilan e-learning di Universitas Pamulang. Diperlukan parameter lain berupa tingkat partisipasi mahasiswa yang terlibat dalam proses pembelajaran kelas online (Budhianto, 2020). Selain itu, sumber lain menyatakan bahwa indikator keberhasilan e-learning adalah tingkat komunikasi dan kolaborasi yang tinggi. Komunikasi mencerminkan proses interaksi dan negosiasi bagi mahasiswa untuk mencapai makna dalarn pembelajaran. Sementara kolaborasi memungkinkan mahasiswa membentuk komunitas belajar yang dapat membantu memperoleh pembelajaran yang bermakna (Wagimin, Ninghardjanti, \& Kristiani, 2014). Hal ini berkaitan dengan intensitas interaksi mahasiswa dan dosen di forum diskusi. Pertimbangan berikutnya adalah bentuk bahan diskusi yang disajikan apakah berkorelasi dengan modul pembelajaran. Mengingat pemeriksaan yang cermat dari konten perlu dipertimbangkan. Desain dan konten elearning yang menarik dan praktis sangat penting. Materi dilengkapi penjelasan yang cukup dan juga latihan. Selain itu, desain dan isi pembelajaran harus dievaluasi dan direvisi dari waktu ke waktu (Kuama \& Intharaksa, 2016). Hal - hal tersebut adalah tantangan untuk mengelola kualitas pembelajaran di Universitas Pamulang, khususnya 
dalam pembelajaran online. Kemudian untuk menjawab tantangan tersebut, dirancang sebuah sistem informasi yang dapat mengotomatiskan pengukuran dengan menerapkan batasan dalam bentuk aktifitas, intensitas, partisipasi, dan kesesuaian konten sebagai parameter pengukuran. Sistem yang dibangun akan membantu dalam meninjau hasil pengukuran dengan beberapa batasan yang disebutkan di atas sehingga program studi yang memiliki persentase rendah dapat diidentifikasi dengan cepat.

\section{Metode Penelitian}

Beberapa tahapan dari metode penelitian yang dilakukan dirinci menjadi proses-proses sebagai berikut:

a. Observasi

Proses observasi dilakukan untuk melihat aktifitas dosen berupa create, update dan delete berdasarkan log e-learning.

b. Wawancara

Wawancara dilakukan untuk mengetahui permasalahan yang ada, wawancara tersebut dilakukan terhadap staf Lembaga Pengembangan Pendidikan dan Pembelajaran.

c. Studi Pustaka

Untuk mencapai tujuan penelitian, maka perlu mempelajari buku, artikel maupun jurnal mengenai teori-teori yang memiliki kaitan dengan penelitian ini.

\section{Model Perhitungan}

Penerapan parameter dalam penelitian ini adalah aktifitas, partisipasi, intensitas, dan kesesuaian konten. Untuk menghitung nilai aktifitas, diperoleh saat dosen membuat topik diskusi, mengupload bahan ajar dan memberikan komentar. Untuk aktifitas dapat ditentukan besarannya, pengukuran lainnya adalah nilai partisipasi mahasiswa (Partisipasi) yang dirumuskan sebagai berikut:

$$
\text { Partisipasi }=\frac{\text { Jumlah Mahasiswa Aktif }}{\text { Jumlah Mahasiswa Terdaftar }} \times 100 \%
$$

Keterangan:

(1) Jumlah Mahasiswa Terdaftar adalah jumlah mahasiswa yang telah terdaftar di satu course.

(2) Jumlah Mahasiswa Aktif adalah jumlah mahasiswa yang memberikan tanggapan terhadap topik diskusi di satu course pada satu pertemuan yang dionlinekan pada jadwal yang diatur.
Parameter lainnya yaitu intensitas, untuk menentukan intensitas maka perlu dilakukan perhitungan sebagai berikut:

Tabel 1. Ketentuan Nilai Keaktifan Dosen

\begin{tabular}{|c|c|c|c|c|}
\hline No. & CM & CD & $\mathbf{A i}$ & $\mathbf{K i}$ \\
\hline 1. & $\mathrm{M}_{1}$ & $\mathrm{D}_{1}$ & $\mathrm{M}_{1} \mathrm{X} \mathrm{P}$ & 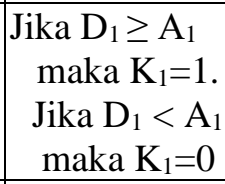 \\
\hline 2. & $\mathrm{M}_{2}$ & $\mathrm{D}_{2}$ & $\mathrm{M}_{2} \mathrm{X} \mathrm{P}$ & $\begin{array}{c}\text { Jika } \mathrm{D}_{2} \geq \mathrm{A}_{2} \\
\text { maka } \mathrm{K}_{2}=1 . \\
\text { Jika } \mathrm{D}_{2}<\mathrm{A}_{2} \\
\text { maka } \mathrm{K}_{2}=0\end{array}$ \\
\hline 3. & $\mathrm{M}_{3}$ & $\mathrm{D}_{3}$ & $\mathrm{M}_{3} \mathrm{XP}$ & $\begin{array}{c}\text { Jika } D_{3} \geq A_{3} \\
\text { maka }_{3}=1 \\
\text { Jika } D_{3}<A_{3} \\
\text { maka } K_{3}=0\end{array}$ \\
\hline 4. & $\mathrm{M}_{4}$ & $\mathrm{D}_{4}$ & $\mathrm{M}_{4} \mathrm{X} \mathrm{P}$ & 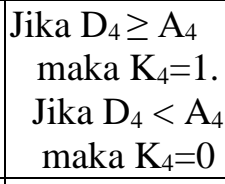 \\
\hline .. & $\ldots$ & $\ldots$ & $\ldots$ & \\
\hline $\mathrm{t}$ & $\mathrm{M}_{\mathrm{t}}$ & $D_{t}$ & $\mathrm{M}_{\mathrm{t}} \mathrm{X} \mathrm{P}$ & $\begin{array}{c}\text { Jika } D_{t} \geq A_{t} \\
\text { maka } K_{t}=1 \\
\text { Jika } D_{t}<A_{t} \\
\text { maka } K_{t}=0\end{array}$ \\
\hline
\end{tabular}

Keterangan :

(1) P : persentase keaktifan dosen perhari yang ditetapkan

(2) $\mathrm{CM}$ : aktifitas mahasiswa

(3) CD : aktifitas dosen

(4) $\mathrm{Ci}:$ aktifitas dosen minimum hari ke-i, i : 1, $2,3, \ldots$

(5) Ki : keaktifan dosen hari ke-i, i : 1, 2, 3, ...

(6) $\mathrm{t}$ : jumlah hari yang disediakan untuk melaksanakan e-learning wajib maupun pengganti

Untuk menentukan intensitas menggunakan perumusan sebagai berikut:

$$
I=\left(\frac{\sum_{i=1}^{t} K i}{t}\right) \times 100 \%
$$

Jika I $\geq \mathrm{Pk}$ maka dianggap dosen bersangkutan aktif pada forum diskusi pertemuan ke-n, yang mana $\mathrm{Pk}$ merupakan persentase keputusan akhir yang ditetapkan. 
Parameter keempat yang digunakan dalam penelitian ini yaitu kesesuaian konten, yang dirumuskan sebagai berikut:

$$
\begin{aligned}
& \text { Kesesuaian konten } \\
& =\frac{\text { Kata Yang Diambil dari Forum Diskusi }}{\text { Kata Yang Diambil dari Modul }} \times 100 \%
\end{aligned}
$$

Keterangan :

(1) Kata Yang Diambil dari Forum Diskusi adalah jumlah kemunculan kata pada forum diskusi yang sesuai dengan keyword pada setiap modul

(2) Kata Yang Diambil dari Modul adalah jumlah keyword yang ditetapkan pada setiap modul

\section{Model Pengembangan Sistem}

Model pengembangan sistem yang digunakan dalam penelitian ini adalah Rapid Application Development (RAD). RAD adalah satu model pengembangan perangkat lunak yang memiliki kelebihan dalam hal pengembangan aplikasi yang cepat dengan tetap mempertahankan kualitas produk (Delima, Santosa, \& Purwadi, 2017). Proses analisis didahului dengan mengidentifikasi rutinitas dan pola pembelajaran menggunakan e-learning. Hasil yang diharapkan adalah sistem informasi untuk mengecek dan mengevaluasi e-learning dengan beberapa parameter yang akan diukur, seperti aktifitas, partisipasi, intensitas, dan kesesuaian konten. Dengan model pengembangan aplikasi yang cepat dan bersifat incremental, komponen atau fungsi dikembangkan secara paralel seolah-olah adalah proyek kecil. Berikut ini adalah skema pengembangan RAD dalam penelitian ini (Sukamto \& Shalahudin, 2016):

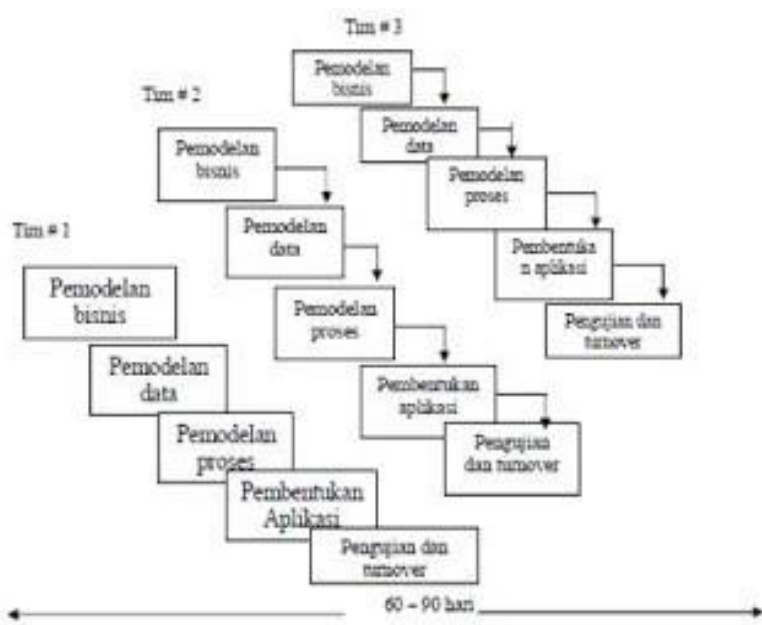

Gambar 1. Skema Pengembangan RAD

\section{a. Pemodelan Bisnis}

Pada bagian awal dilakukan pemodelan fungsi bisnis dengan agar lebih memahami informasi terkait proses bisnis, informasi yang dibutuhkan, siapa yang menjadi sumber informasi, dan bagaimana informasi itu diproses.

b. Pemodelan Data

Pada bagian ini dibuat sebuah pemodelan tentang data apa saja yang diperlukan dengan mengacu kepada pemodelan bisnis dan menerjemahkan komponen - komponen seperti atribut, relasi dan lain-lain.

c. Pemodelan Proses

Proses selanjutnya yaitu menerapkan fungsi bisnis yang sudah diterjemahkan terkait dengan pendefinisian data.

d. Pembentukan Aplikasi

Pada tahapan ini, apa yang telah dibuat pada pemodelan proses dan data diimplementasikan ke dalam program.

e. Pengujian dan Turnover

Ini merupakan tahapan akhir dari serangkaian tahapan dalam model RAD. Prosesnya dengan menguji komponen-komponen yang telah dibuat. Jika komponen yang diujikan telah dinyatakan valid, maka tim pengembang akan melanjutkan pengembangan komponen berikutnya.

\section{Hasil dan Pembahasan}

Bagian ini akan menjelaskan mengenai langkah-langkah penyelesaian masalah dalam mengukur efektivitas e-learning. Proses pertama dimulai dengan melakukan pengumpulan data melalui observasi dan wawancara dengan Lembaga Pengembangan Pendidikan dan Pembelajaran (LP3). Tahapan berikutnya dengan mengidentifikasi masalah. Dari proses pengumpulan data dapat diidentifikasi masalah yaitu banyaknya course yang disediakan akan mempengaruhi aktifitas pemantauan e-learning. Keterbatasan menjadi kendala dikarenakan pemantauan hanya dilakukan dengan melihat setiap aktifitas dosen yang tercatat di log e-learning. Namun, dari log tersebut tidak dapat memberikan informasi terkait efektivitas pada pembelajaran online. Log yang tercatat hanya menampilkan aktifitas create, update dan delete yang dilakukan oleh dosen pada forum diskusi, sehingga belum dapat dijadikan sebagai tolak ukur terhadap keberhasilan e-learning di Universitas Pamulang. Selain itu dirasa perlu untuk menetapkan parameter lain untuk mengukur tingkat intensitas interaksi mahasiswa dan dosen di forum diskusi, tingkat partisipasi mahasiswa yang terdaftar pada suatu 
course, dan materi diskusi yang disajikan apakah telah memiliki korelasi dengan modul pembelajaran atau tidak. Tentu ini menjadi tantangan dalam mengelola mutu pembelajaran di Universitas Pamulang.

Dari masalah di atas, perlu dilakukan perbaikan untuk meningkatkan efektivitas elearning. Salah satunya dengan membuat sistem yang dapat mempermudah proses monitoring dan evaluasi e-learning dengan penerapan parameter berupa aktifitas, partisipasi, intensitas dan kesesuaian konten.
Tahapan berikutnya yaitu merancang sebuah sistem baru dalam bentuk skema database dan alur sistem. Database (Basis Data) adalah kumpulan data yang saling berhubungan secara logis dan didesain untuk mendapatkan data yang dibutuhkan oleh suatu organisasi (Indrajani, 2015). Sementara alur sistem digambarkan dengan use case diagram yang mendeskripsikan sebuah interaksi antara satu atau lebih aktor dengan sistem informasi yang akan dibuat (Rosa \& Shalahuddin, 2013). Kedua skema tersebut digambarkan sebagai berikut: a. Use Case Diagram

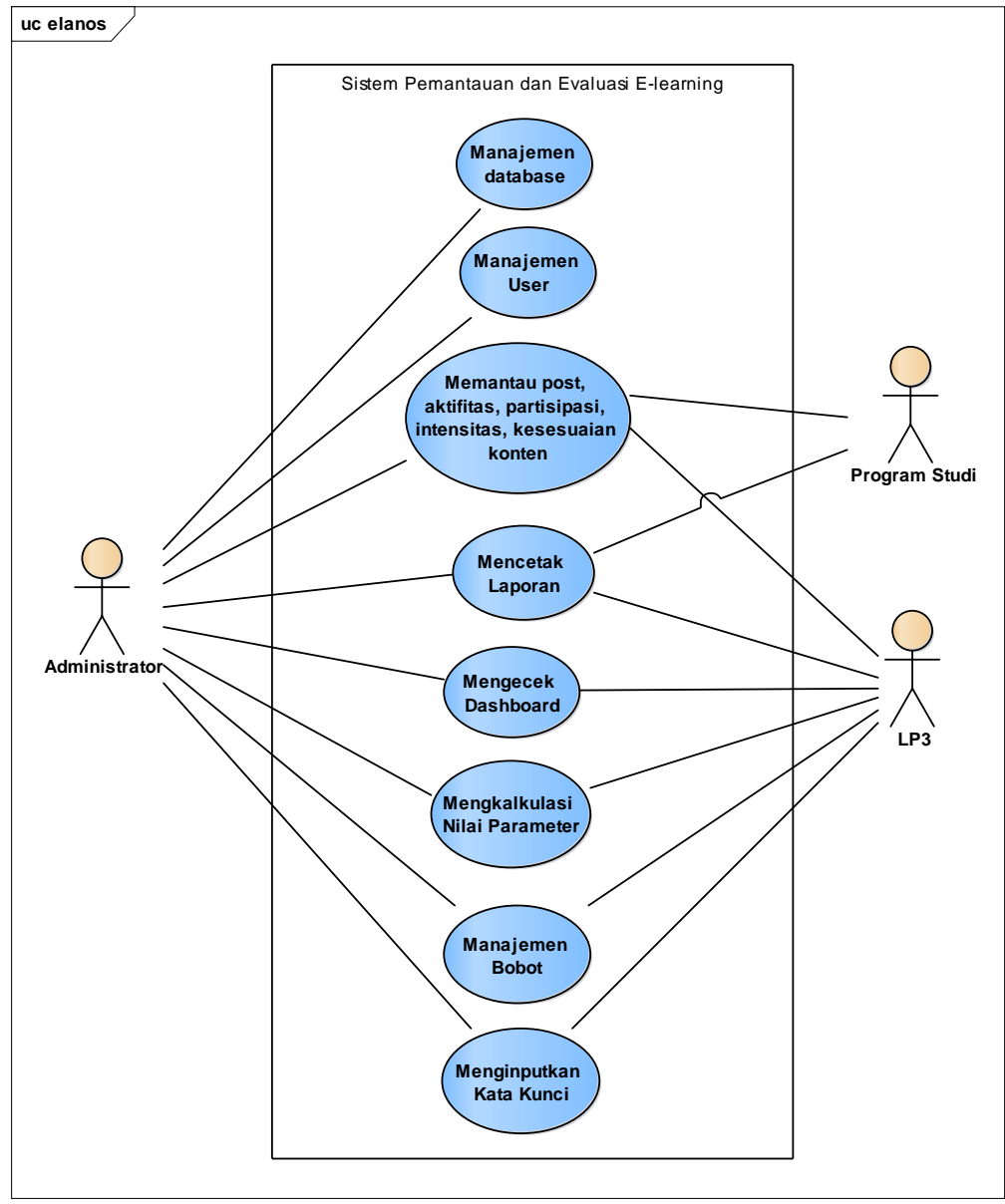

Gambar 2. Pemodelan Use Case

Pada use case di atas menggambarkan bahwa sistem ini dirancang untuk 3 pengguna / actor yaitu administrator, Program Studi dan LP3. Dari menu administrator dapat melaksanakan seluruh aktifitas yang ada pada sistem seperti manajemen manajemen database dan user, mengecek dashboard, melakukan pemantauan terhadap post, aktifitas, partisipasi, intensitas dan kesesuaian konten. Kemudian dari menu LP3 dapat melakukan aktifitas layaknya administrator, namun akses untuk manajemen user dan manajemen database dibatasi. Dari menu Program Studi aktifitas yang dilakukan terbatas pada melakukan pemantauan terhadap post, aktifitas, partisipasi, intensitas dan kesesuaian konten dan mencetak laporan. 
b. Skema Database
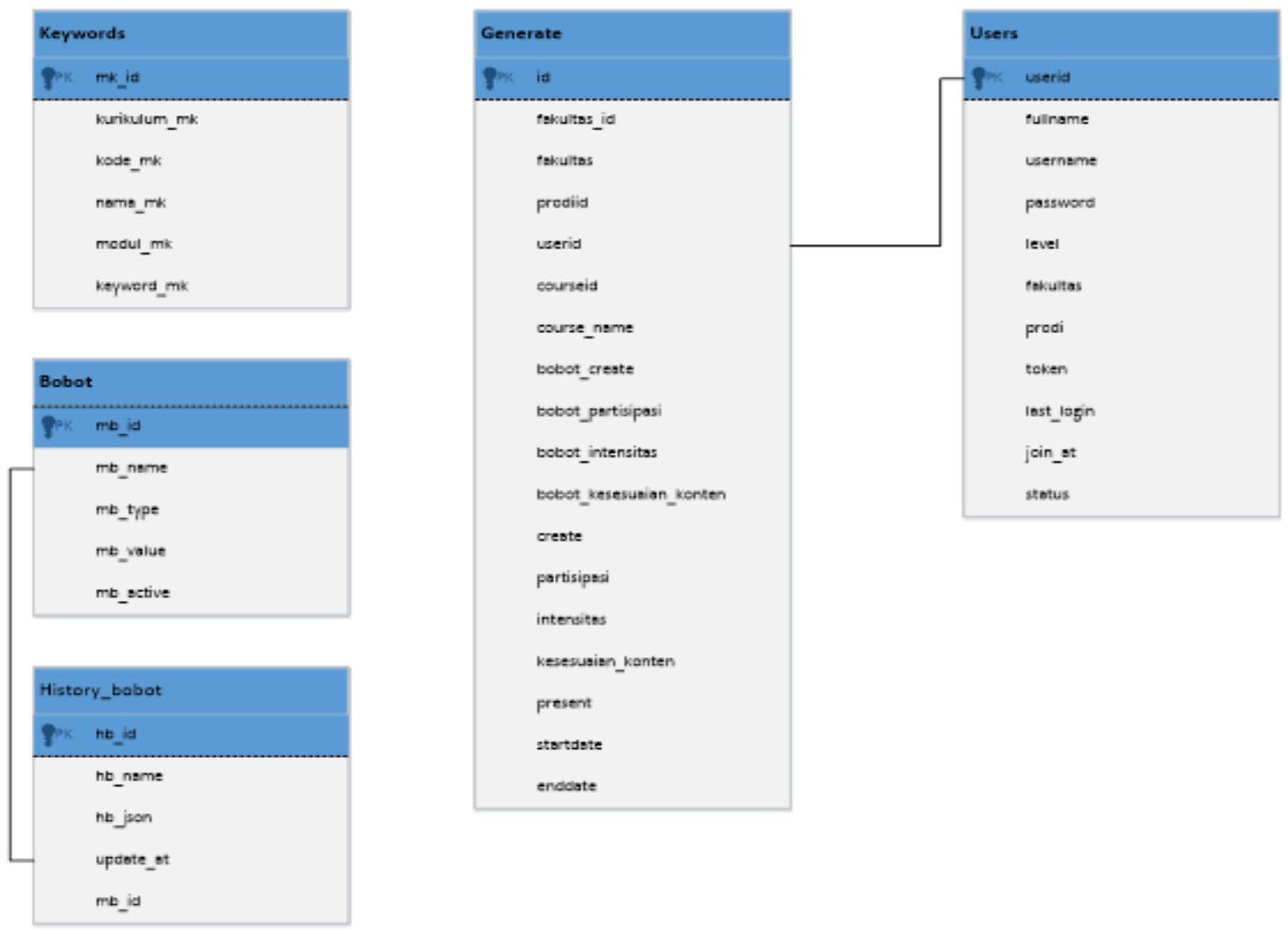

Gambar 3. Skema Database

Tahapan selanjutnya adalah mengimplementasikan sistem berdasarkan skema yang telah dirancang pada skema database dan use case diagram. Aplikasi dibuat berbasis web, untuk mempermudah user mengakses penilaian parameter-parameter yang ditentukan.

Tahap selanjutnya adalah pengujian atau evaluasi. Tahapan ini dilakukan untuk mengukur seberapa besar dampak pelaksanaan e-learning

ataupun hasil akhir yang diharapkan terhadap peningkatan kinerja dosen dan menekankan seberapa besar e-learning membangun kreativitas belajar bagi mahasiswa atas materi e-learning dalam konteks peningkatan pengetahuan dan kompetensi.

Pengujian menggunakan data e-learning 8 Program Studi periode 9 Maret sampai dengan 13 Maret 2020. Dengan hasil sebagai berikut:

Tabel 2. Rata-rata Penilaian Program Studi

\begin{tabular}{|l|l|l|l|l|l|}
\hline No. & Program Studi & $\begin{array}{l}\text { Persentase Rata-rata } \\
\text { aktifitas }\end{array}$ & $\begin{array}{l}\text { Persentase Rata-rata } \\
\text { Partisipasi Mahasiswa }\end{array}$ & $\begin{array}{l}\text { Persentase } \\
\text { Rata-rata } \\
\text { Intensitas }\end{array}$ & $\begin{array}{l}\text { Persentase Rata- } \\
\text { rata Kesesuaian } \\
\text { Konten }\end{array}$ \\
\hline 1. & D3 Akuntansi & 77,84 & 92,63 & 57,65 & 0 \\
\hline 2. & Ilmu Hukum & 81,07 & 86,61 & 54,83 & 0 \\
\hline 3. & Matematika & 70,23 & 63,11 & 44,52 & 0 \\
\hline 4. & S1 Manajemen & 79,37 & 89,48 & 55,13 & 0,35 \\
\hline 5. & Teknik Elektro & 69,74 & 70,66 & 43,7 & 0 \\
\hline 6. & Teknik Industri & 69,61 & 77,69 & 61,03 & 0 \\
\hline 7. & $\begin{array}{l}\text { Teknik } \\
\text { Informatika }\end{array}$ & 17,38 & 55,33 & 32,50 & 0 \\
\hline 8. & Teknik Kimia & 62,03 & & & 0 \\
\hline \multicolumn{2}{r}{ Rata-rata } & 65,90 & 64,42 & 45,81 & 0 \\
\hline
\end{tabular}




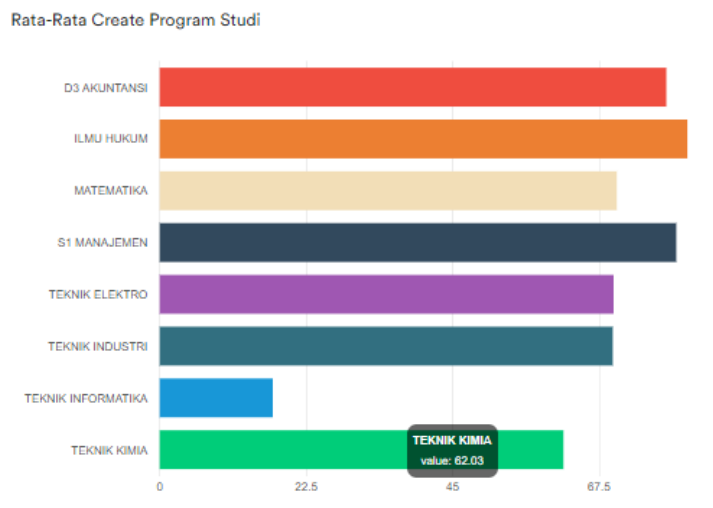

Rata-Rata Persentase Intensitas Aktivitas Elearning

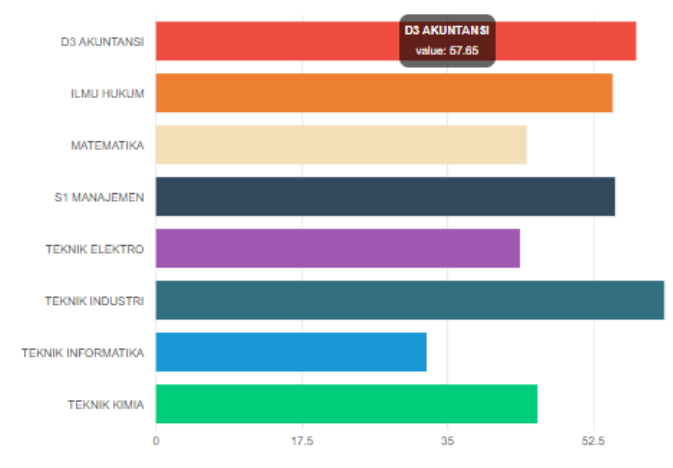

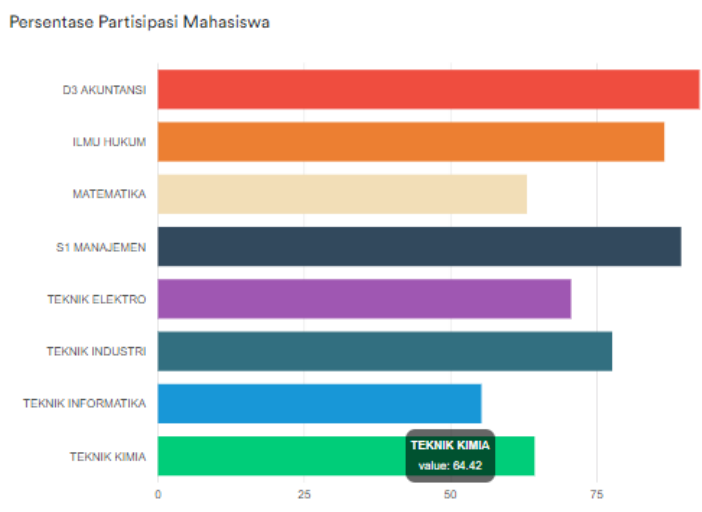

Ket : Persentase dari jum

Kesesuaian Konten Prod

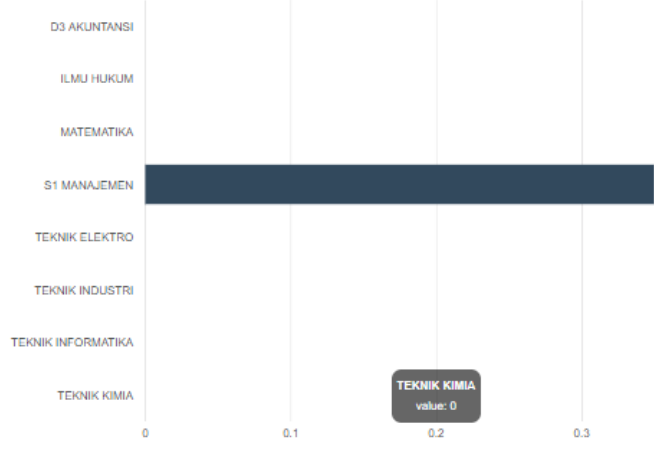

Gambar 4. Deskripsi Rata-rata penilaian Program Studi

Data pada tabel dan gambar di atas, menekankan pada pencapaian beberapa parameter. Efektivitas ditunjukkan dengan persentase nilai aktifitas (create), partisipasi, intensitas dan kesesuaian konten. Nilai yang diperoleh pada masing - masing program studi dapat bervariasi. Dari data yang diujikan yang memiliki nilai aktifitas tertinggi yaitu Program Studi Ilmu Hukum dengan nilai $81,07 \%$. Nilai tertinggi dari parameter partisipasi yaitu Program Studi 92,63\%. Kemudian untuk parameter intensitas nilai tertinggi diperoleh Program Studi Teknik Industri yaitu 61,03\%. Dan untuk parameter kesesuaian konten nilai tertinggi diperoleh Program Studi S1 Manajemen yaitu $0,35 \%$.

\section{Kesimpulan}

Berdasarkan pembahasan yang telah dijabarkan, maka dapat disimpulkan bahwa dalam proses pemantauan dan evaluasi keefektifan elearning pada 8 Program studi yang telah disebutkan, menunjukkan setiap hari dalam periode yang ditentukan, mahasiswa menggunakan e- learning sebagai mekanisme pembelajaran. Hal ini diungkapkan dengan tingkat partisipasi mahasiswa yang aktif dalam forum diskusi rata-rata 74,99\%, angka ini menunjukkan antusiasme mahasiswa cukup tinggi karena pembelajaran dapat dilakukan kapanpun tanpa terbatas waktu. Perbandingan intensitas keaktifan dosen dan mahasiswa menggunakan e-learning setiap hari dalam seminggu selama periode pelaksanaan sebesar 49,40\%. Angka ini dipengaruhi oleh mahasiswa yang hanya aktif di awal dan akhir periode elearning. Dalam hal kesesuaian konten didapatkan rata-rata $0,04 \%$ karena isi dari forum diskusi tidak selalu bersinggungan dengan kata kunci yang ditetapkan. Sementara untuk nilai rata-rata aktifitas dosen sebesar 65,90\%, hal ini menunjukkan tingkat keaktifan dosen dalam membangun dan memotivasi kreativitas mahasiswa dalam pembelajaran berbasis e-learning cukup tinggi.

\section{Daftar Pustaka}

Asosiasi Penyelenggara Jasa Internet Indonesia. (2019). Hasil Survei Penetrasi dan Perilaku Pengguna 
Internet Indonesia 2018. Jakarta: Asosiasi Penyelenggara Jasa Internet Indonesia.

Budhianto, B. (2020). Analisis Perkembangan Dan Faktor Yang Mempengaruhi Keberhasilan Pembelajaran Daring ( E - Learning ). Jurnal AgriWidya Vol. 1 NO. 1 Maret 2020, 11-29.

Delima, R., Santosa, H. B., \& Purwadi, J. (2017). Development of Dutatani Website Using Rapid Application Development. IJITEE, Vol. 1, No. 2, June 2017, 36-44.

Dhull, I., \& Sakshi, M. (2017). International Education \& Research Journal [IERJ] Vol 3, No. 8, 3234.

Indrajani. (2015). Database Design (Case Study All in One). Jakarta: PT Elex Media Komputindo.

Kuama, S., \& Intharaksa, U. (2016). Is Online Learning Suitable for All English Language Students? PASAA Vol. 52 July - December 2016, 53-82.

Pangondian, R. A., Santosa, P. I., \& Nugroho, E. (2019). Faktor - Faktor Yang Mempengaruhi Kesuksesan Pembelajaran Daring Dalam Revolusi Industri 4.0. Seminar Nasional Teknologi Komputer \& Sains (SAINTEKS) (pp. 56-60). Medan: STMIK Budi Darma.

Rosa, A., \& Shalahuddin, M. (2013). Rekayasa Perangkat Lunak Terstruktur dan Berorientasi Objek. Bandung: Informatika.

Silahuddin. (2015). Penerapan E-Learning dalam Inovasi Pendidikan. Jurnal Ilmiah CIRCUIT Vol. 1 No. 1 Juli 2015, 48-59.

Sukamto, R. A., \& Shalahudin, M. (2016). Rekayasa Perangkat Lunak. Bandung: Informatika Bandung.

Wagimin, I., Ninghardjanti, P., \& Kristiani. (2014). Model Kesuksesan Pembelajaran dengan ELearning di Perguruan Tinggi . Jurnal Penelitian Pendidikan INSANI, Vol. 16, No. 1, Juni 2014, 23-35. 